\title{
SELECTION AMONG SEGREGATING PEPPER PROGENIES WITH ORNAMENTAL POTENTIAL USING MULTIVARIATE ANALYSES ${ }^{1}$
}

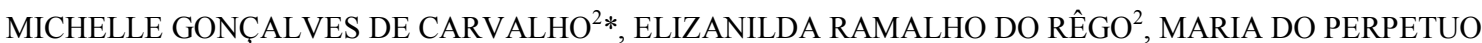 \\ SOCORRO DAMASCENO COSTA ${ }^{2}$, ANGELA MARIA DOS SANTOS PESSOA ${ }^{3}$, MAILSON MONTEIRO DO RÊGO ${ }^{2}$
}

\begin{abstract}
Peppers belong to the family Solanaceae and can be used for several different purposes. The use of morphological descriptors associated with multivariate techniques allows identifying pepper progenies that can be recommended for ornamental purposes. This study aimed to select segregating Capsicum annum progenies based on multivariate analyses. The study was conducted in a plant nursery at the Biotechnology and Plant Breeding Sector of the Center of Agricultural Sciences of the Federal University of Paraíba (CCA/ UFPB). Twenty $F_{3}$ progenies of ornamental peppers were used, namely: UFPB 5, 8, 10, 15, 18, 22, 25, 32, 33, $36,40,42,49,56,60,62,64,69,75$, and 77, plus four additional controls consisting of the parents UFPB 77.3 and UFPB137 and two commercial cultivars, Etna and Pirâmide. Seventeen plant and fruit traits were evaluated. The experimental design was completely randomized. The data were subjected to a multivariate analysis of variance. All analyses were performed with the software R, version 3.0.3. The results of the multivariate analysis of variance highlighted significant differences between the populations of ornamental peppers. Singh's (1981) method made it possible to determine that eleven of the seventeen traits studied contributed with $73.7 \%$ of the genetic divergence, whereas six traits contributed with only $21.2 \%$. There is genetic diversity among the evaluated progenies. Progenies 5, 10, 22, 33, 49, and 69 are recommended for selection for having ornamental traits for in-pot cultivation. Selection within these progenies is recommended to continue the breeding program of ornamental peppers for in-pot cultivation.
\end{abstract}

Keywords: Capsicum. Breeding. Variability.

\section{SELEÇÃO ENTRE PROGÊNIES SEGREGANTES DE PIMENTEIRAS COM POTENCIAL ORNAMENTAL UTILIZANDO ANÁLISES MULTIVARIADAS}

\begin{abstract}
RESUMO - As pimenteiras pertencem à família Solanaceae e podem ser utilizadas com diferentes finalidades. $\mathrm{O}$ uso de descritores morfológicos associados a técnicas multivariadas possibilita identificar progênies de pimenteiras que podem ser recomendadas para fins ornamentais. O objetivo desse trabalho foi selecionar progênies segregante de Capiscum annum com base em análises multivariadas. O trabalho foi realizado em casa de vegetação no Setor de Biotecnologia e Melhoramento Vegetal no Centro de Ciências Agrárias da Universidade Federal da Paraíba. Foram utilizadas 20 progênies $F_{3}$ de pimenteiras ornamentais, UFPB: 5, 8, 10, $15,18,22,25,32,33,36,40,42,49,56,60,62,64,69,75$ e 77 e quatro testemunhas adicionais, os genitores UFPB 77.3, UFPB137 e duas cultivares comerciais, Etna e Pirâmide. Foram avaliadas 17 características de planta e frutos. O delineamento experimental utilizado foi inteiramente casualizado. Os dados foram submetidos à análise de variância multivariada. Todas as análises foram realizadas com software $\mathrm{R}$ versão 3.0.3. Os resultados da análise de variância multivariada indicaram diferença significativa entre as populações de pimenteiras ornamentais. Através do método de Singh (1981), determinou-se que onze das dezessete características estudadas contribuíram com 73,7 \% da divergência genética, enquanto seis características contribuíram com apenas $21,2 \%$. Existe diversidade genética entre as progênies avaliadas. As progênies 5, 10, 22, 33, 49 e 69 são indicadas para seleção por apresentarem características ornamentais de vaso. Recomenda-se a seleção dentro dessas progênies dando continuidade ao programa de melhoramento de pimenteiras ornamentais em vaso.
\end{abstract}

Palavras-chave: Capsicum. Melhoramento. Variabilidade.

\footnotetext{
${ }^{*}$ Corresponding author

${ }^{1}$ Received for publication in $06 / 08 / 2020$; accepted in $03 / 11 / 2021$.

Paper extracted from the master's dissertation of the first author.

${ }^{2}$ Center for Agricultural Sciences, Universidade Federal da Paraíba, Areia, PB, Brazil; carvalho.areia@hotmail.com - ORCID: 0000-00015541-7047, elizanilda@cca.ufpb.br - ORCID: 0000-0001-7376-7569, agro30costa@gmail.com - ORCID: 0000-0001-8495-6808, mailson@cca.ufpb.br - ORCID: 0000-0003-3096-6992.

${ }^{3}$ Department of Phytotechnics, Universidade Federal do Ceará, Fortaleza, CE, Brazil; angelapessoapb@gmail.com - ORCID: 0000-00027393-984X
} 


\section{INTRODUCTON}

In the last few years, the flower and ornamental plant sector has shown an increasing demand in Brazil (IBRAFLOR, 2018). Peppers are among the plants with ornamental potential, belonging to the genus Capsicum and the family Solanaceae (PICKERSGIL, 1997; STOMMEL; BOSLAND, 2006), with wide genetic diversity and a great variety of uses (NEITZKE et al., 2016). This is one of the most important crops worldwide due to its high versatility and a wide spectrum of uses in the industry, as food (SILVAR; GARCÍA-GONZÁLEZ, 2017; BARCHENGER; LAMOUR; BOSLAND, 2018.), and also as ornamental plants (REGO; RÊGO, 2016; 2018). Furthermore, peppers are autogamous species easily propagated by seeds, with short vegetative phases and high aesthetical value (RÊGO et al., 2012; RÊGO; RÊGO, 2018; NASCIMENTO et al., 2019).

Aiming at meeting the demands of a growing market, breeders and producers have been encouraged to develop new cultivars with attractive traits for ornamental purposes (RÊGO; RÊGO, 2016). Therefore, the search for peppers with ornamental potential has grown due to attributes that provide these plants with an excellent aesthetical value, such as variegated foliage, compact size, and fruits with various colors in the different maturation stages, contrasting with the leaves (MELO et al., 2014; RÊGO; RÊGO, 2018; PESSOA et al., 2018), in addition to remarkable adaptability to smallersized pots.

The genetic variability among Capsicum species is the basic condition for the genetic improvement of this genus, allowing its use and knowledge for the development of new pepper varieties.

Breeding programs are based on the presence of variability for the trait meant to be improved; genetic divergence studies are extremely important in these programs in order to identify superior genotypes and/or progenies with traits of interest (CRUZ; REGAZZI; CARNEIRO, 2012; PESSOA et al., 2018).

In order to obtain new and superior pepper strains, it is necessary to perform selection during successive self-fertilization cycles in segregating populations (MESQUITA et al., 2016; PESSOA et al., 2019). Variability studies with ornamental peppers are based on plant, flower, and fruit traits, evaluating qualitative and quantitative data (BARROSO et al., 2012; SILVA NETO et al., 2014; COSTA et al., 2016; LIMA et al., 2019; FORTUNATO et al., 2019; PESSOA et al., 2019; NASCIMENTO et al., 2019). Through morphological characterization, it is possible to assess the genetic divergence of a set of available genotypes for use in genetic improvement programs
(ELIAS et al., 2007).

Selecting these individuals requires evaluating the genetic divergence using biometric models, which are based on multivariate techniques that allow combining the multiple data of a set of traits (CRUZ; CARNEIRO, 2006; MESQUITA et al., 2016).

In view of this, this study aimed to select segregating progenies of Capsicum annuum based on multivariate analyses.

\section{MATERIAL AND METHODS}

The study was conducted in a plant nursery of the Laboratory of Plant Biotechnology of the Center of Agricultural Sciences (CCA) of the Federal University of Paraíba (UFPB), in Areia - PB, at an elevation of $618 \mathrm{~m}, 06^{\circ} 57^{\prime} 48^{\prime \prime} \mathrm{S}$ and $35^{\circ} 41^{\prime} 30^{\prime \prime} \mathrm{W}$.

The plant material consisted of 20 progenies of an $\mathrm{F}_{3}$ generation of ornamental peppers (C. annuum L.) $(5,8,10,15,18,22,25,32,33,36$, $40,42,49,56,60,62,64,69,75$, and 77), belonging to the Active Germplasm Bank of the genus Capsicum of UFPB, originated from the controlled self-fertilization of accessions selected from an $F_{2}$ generation, which, in turn, were obtained from the self-fertilization of $F_{1}$, originated from the cross between the parent individuals UFPB $77.3 \mathrm{x}$ UFPB 137 (Table 1). Selections were made by the genealogic method; each population analyzed in this study consisted of 20 individuals, in addition to four controls: parents UFPB 77.3 and UFPB 137, and the commercial varieties Etna and Pirâmide; each control had 15 replications.

Sowing was performed in expanded polystyrene trays with 200 cells filled with the commercial substrate Plantmax $\mathrm{HT}^{\circledR}$. At 35 days after sowing, when the seedlings had three pairs of true leaves, they were transplanted to $900-\mathrm{mL}$ plastic pots containing the same substrate. The plants were irrigated daily with water and once a week with a nutrient solution (MESQUITA et al., 2016).

The morpho-agronomic characterization was performed according to the guidelines contained in the descriptor of the genus Capsicum proposed by IPGRI (1995), with the aid of a caliper (Western ${ }^{\circledR}$ ) and a semi-analytical balance (Bel engineering ${ }^{\mathbb{B}}$ ).

Seventeen plant and fruit morphological descriptors were used. The following plant traits were evaluated: plant height (AP), crown diameter (AC), first bifurcation height (APB), stem diameter (DCAU), leaf length (CFO), and leaf width (LFO). The fruit traits evaluated were: pedicel length (CPE), fruit weight $(\mathrm{PF})$, fruit length $(\mathrm{CF})$, largest fruit diameter (MDF), smallest fruit diameter (MEDF), pericarp thickness (EP), placenta length (CPL), fresh matter (MF), number of seeds (NS), dry matter (MS), and number of fruits (NF). 
M. G. CARVALHO et al.

Table 1. Means of the quantitative traits of parents and hybrids of ornamental peppers (Capsicum annuum L.).

\begin{tabular}{cccccc}
\hline \multirow{2}{*}{ Genotypes/UFPB } & \multicolumn{5}{c}{ Traits } \\
\cline { 2 - 6 } & AP & AC & APB & DCAU & CFO \\
\hline 77.3 & 32.25 & 35.12 & 15.87 & 0.63 & 5.68 \\
137 & 22.68 & 30.50 & 10.68 & 0.73 & 5.86 \\
77.3 X 137 & 21.25 & 28.81 & 10.00 & 0.63 & 5.11 \\
\hline \multirow{2}{*}{ Genotypes /UFPB } & LFO & PFR & Traits & CF & NF \\
\cline { 2 - 6 } & 1.87 & 0.33 & 0.99 & 29.00 & 119.37 \\
77.3 & 1.83 & 1.76 & 2.28 & 61.00 & 42.62 \\
77.3 X 137 & 1.64 & 1.73 & 2.43 & 50.50 & 68.00 \\
\hline
\end{tabular}

AP - Plant height $(\mathrm{cm}) ; \mathrm{AC}$ - crown diameter $(\mathrm{cm})$; APB - first bifurcation height $(\mathrm{cm})$; DCAU - stem diameter $(\mathrm{cm})$; CFO - leaf length $(\mathrm{cm}) ; \mathrm{LFO}$ - leaf width $(\mathrm{cm}) ; \mathrm{PFR}$ - fruit weight $(\mathrm{cm}) ; \mathrm{CF}$ - fruit length $(\mathrm{cm})$; NS - number of seeds; and NF - number of fruits per plant.

The experimental design was completely randomized, and the experimental unit consisted of one plant per pot. The data were subjected to a multivariate analysis of variance. The use of multivariate techniques is one of the factors that have boosted the number of studies on the genetic diversity among genotypes. Multivariate analysis has been employed for both quantitative and qualitative traits, allowing the breeder to better discriminate between genotypic and phenotypic divergence in several plant species (OLIVEIRA; SCAPIM; CASALI, 1998; COSTA et al., 2006; NASCIMENTO et al., 2011; VIANA; RESENDE, 2014).

In order to quantify the relative contribution of the traits to genetic divergence, Singh's (1981) criterion was used based on the generalized Mahalanobis distance matrix. Subsequently, canonical discriminant variables were constructed, whose mean scores for each family were presented in the two-dimensional space using the biplot method. The Scott-Knott criterion was used to classify the genotypes based on the scores of the first canonical variable. All analyses were performed with the software R, version 3.0.3 (R DEVELOPMENT CORE TEAM, 2014).

\section{RESULTS AND DISCUSSION}

The results of the multivariate analysis of variance indicated a significant difference at $0.001 \%$ of significance by the F-test, demonstrating the existence of a differentiated behavior among the progenies and variability for the morphoagronomical traits (Table 2). The presence of variability verified in these populations favors the development of new pepper cultivars with ornamental potential.

Table 2. Summary of the multivariate analysis of variance (MANOVA) for morpho-agronomic traits in populations of ornamental peppers (Capsicum annuum L.).

\begin{tabular}{ccccccc}
\hline S.V. & DOF & Pillai statistics & $\begin{array}{c}\text { F } \\
\text { statistics }\end{array}$ & DOF Num & $\begin{array}{c}\text { DOF } \\
\text { Den }\end{array}$ & p value \\
\hline $\begin{array}{c}\text { Populations } \\
\text { Residuals }\end{array}$ & 23 & 5.1 & 8.2 & 391 & 7412 & $2.210^{-16 * * *}$ \\
\hline
\end{tabular}

$* * *$ significant at $0.001 \%$

Pessoa et al. (2019) and Fortunato et al. (2019) also reported significant differences in their studies with segregating Capsicum progenies. These results highlight the existence of genetic variability and the possibility of performing selection among progenies in order to maximize genetic gain (FERRÃO et al., 2011; PESSOA et al., 2018). Variability is essential in the selection of individuals for generation advancement.

Through Singh's (1981) method, it was determined that eleven of the seventeen traits studied contributed with $73.7 \%$ of the genetic divergence, while six traits contributed with only $21.2 \%$ (Figure 1).

Of the studied traits, the ones that most contributed to genetic divergence among the evaluated progenies were leaf length (11.1\%), pedicel length $(9.1 \%)$, largest fruit diameter $(8.3 \%)$, placenta length $(7.8 \%)$, plant height $(7.1 \%)$, number of fruits $(6.6 \%)$, and first bifurcation height $(6.4 \%)$ (Figure 1).

These results can assist in the selection of superior progenies and genotypes, attributing importance to the referred traits in the selection of ornamental peppers (NASCIMENTO et al., 2019). These traits that showed the greatest contributions demonstrated that, even in F2:3, there is still much variability, and these traits should be considered for discriminating between the progenies. 


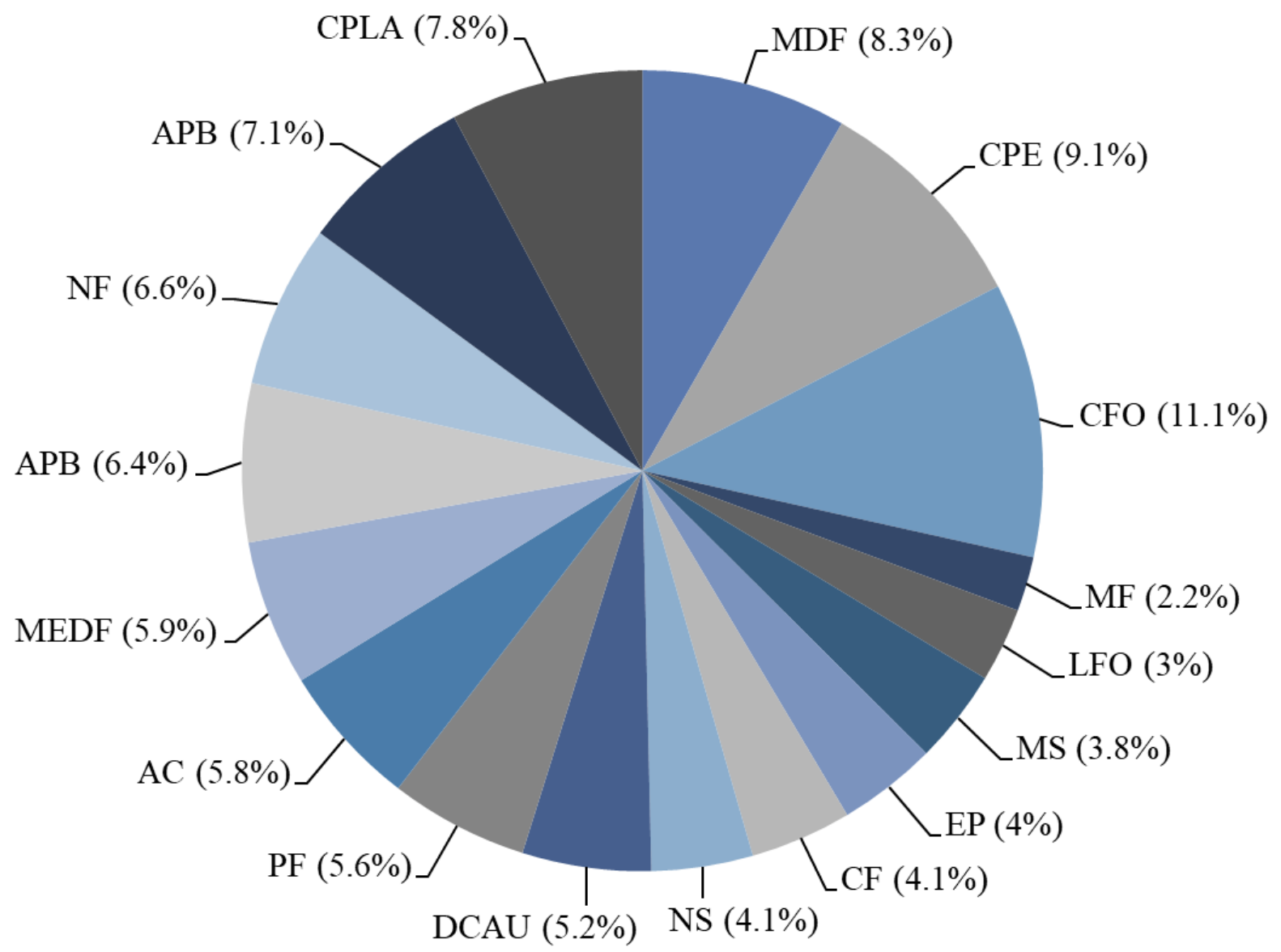

Figure 1. Relative contribution of the morphological descriptors with the calculation of the Mahalanobis distances according to Singh's criterion for the morpho-agronomic traits of Capsicum annuum L. Plant height (AP), crown diameter (AC), first bifurcation height (APB), stem diameter (DCAU), leaf length (CFO), and leaf width (LFO). The fruit traits evaluated were: pedicel length (CPE), fruit weight (PF), fruit length $(\mathrm{CF})$, largest fruit diameter (MADF), smallest fruit diameter (MEDF), pericarp thickness (EP), placenta length (CPLA), fresh matter (MF), number of seeds (NS), dry matter (MS), and number of fruits (NF).

The variables that contributed the least to genetic divergence by Singh's method were fresh matter $(2.2 \%)$, leaf width $(3.0 \%)$, dry matter $(3.8 \%)$, and pericarp thickness (4.0\%) (Figure 1), promoting low-magnitude contributions (Figure 1). Some authors report that these variables that showed low contributions are prone to be discarded in future studies for not contributing to genotype differentiation in diversity studies (CRUZ; REGAZZI; CARNEIRO, 2012). However, these low contributions can be explained by the fact that these progenies show an advanced degree of homozygosis in some traits due to the advanced generation.

The relative importance of the canonical variables was measured by the percentage of their eigenvalues in relation to the total of eigenvalues, that is, the percentage of the total variance that they explain.

In the analysis of the canonical variables, genetic diversity was detected among the ornamental pepper progenies, and the first three variables explained $79.29 \%$ of the total variance (Table 3 ).
The results of the canonical variables were satisfactory and should be used in future analyses, considering that total variations over $70 \%$ were obtained in the first three variables (Table 3), allowing the group analysis of the progenies using the scatter plot. Similar results were observed by Pessoa et al. (2018), Nascimento et al. (2019), and Fortunato et al. (2019) in genetic divergence studies with segregating ornamental pepper progenies, observing that the first three canonical variables explained more than $70 \%$ of the total variation. This value suggests that the graphic representation of the three canonical variables may be appropriate to demonstrate the relationship between and within progenies (FORTUNATO et al., 2019).

According to Bento et al. (2007), when the first three canonical variables explain more than $70 \%$ of the variation, the data fit into a three-dimensional graphic representation, allowing the separation of progenies and being able to be used as a strategy to select divergent genotypes. 
Table 3. Estimates of the variances (eigenvalues) associated with the canonical variables referring to the morphoagronomical traits in ornamental pepper (C. annuum L.) populations.

\begin{tabular}{cccc}
\hline Canonical variables & Eigenvalues & Eigenvalues \% & Cumulative \% \\
\hline CV1 & 10.75 & 48.40 & 48.40 \\
CV2 & 4.34 & 19.53 & 67.93 \\
CV3 & 2.52 & 11.36 & 79.29 \\
CV4 & 1.58 & 7.11 & 86.41 \\
CV5 & 0.75 & 3.41 & 89.82 \\
CV6 & 0.55 & 2.47 & 92.30 \\
CV7 & 0.48 & 2.18 & 94.48 \\
CV8 & 0.45 & 2.03 & 96.51 \\
CV9 & 0.26 & 1.19 & 97.71 \\
CV10 & 0.18 & 0.84 & 98.56 \\
CV11 & 0.12 & 0.54 & 99.10 \\
CV12 & 0.08 & 0.38 & 99.48 \\
CV13 & 0.05 & 0.23 & 99.71 \\
CV14 & 0.03 & 0.16 & 99.87 \\
CV15 & 0.01 & 0.05 & 99.93 \\
CV16 & 0.01 & 0.04 & 99.98
\end{tabular}

Under the conditions of this study, the traits that most contributed to variability were the largest fruit diameter (CAN1) and pedicel length (CAN2) (Table 4). According to the weighting coefficients, the traits that contributed the least to genetic diversity were the number of seeds (CAN1) and fresh matter (CAN2) (Table 4).
These traits should be discarded in future studies since, in the analysis of canonical variables, the traits that show the highest weighting coefficients are discarded (CRUZ; FERREIRA; PESSONI, 2011), saving time, work, and financial resources in future studies (NASCIMENTO et al., 2019; YOKOMIZO; NETO; OLIVEIRA, 2017).

Table 4. Weighting coefficients (eigenvalues) associated with the canonical variables of the 17 traits in ornamental pepper (C. annuum L.) populations.

\begin{tabular}{cccc}
\hline Traits & CAN1 & CAN2 & CAN3 \\
\hline AP & 0.01 & 0.23 & -0.43 \\
AC & -0.07 & 0.12 & -0.44 \\
APB & -0.06 & 0.36 & 0.24 \\
DCAU & -0.03 & -0.04 & 0.43 \\
CFO & -0.33 & -0.58 & 0.27 \\
LFO & 0.01 & 0.13 & -0.23 \\
CPE & 0.24 & 0.56 & 0.09 \\
PF & 0.06 & -0.13 & 0.37 \\
CF & -0.12 & 0.04 & -0.04 \\
MEDF & 0.69 & -0.31 & -0.29 \\
MADF & 0.33 & -0.01 & -0.14 \\
EP & 0.09 & 0.17 & -0.05 \\
CPLA & -0.13 & 0.55 & 0.59 \\
MF & 0.60 & -0.62 & -0.07 \\
NS & -0.60 & 0.07 & -0.11 \\
MS & -0.44 & 0.11 & 0.06 \\
NF & -0.26 & -0.13 & -0.29 \\
\hline
\end{tabular}

Plant height (AP), crown diameter (AC), first bifurcation height (APB), stem diameter (DCAU), leaf length (CFO), and leaf width (LFO). The fruit traits evaluated were: pedicel length (CPE), fruit weight (PF), fruit length $(\mathrm{CF})$, largest fruit diameter (MADF), smallest fruit diameter (MEDF), pericarp thickness (EP), placenta length (CPLA), fresh matter (MF), number of seeds (NS), dry matter (MS), and number of fruits (NF). 
The variability retained by the first canonical variable was $48.4 \%$. However, the second canonical variable resulted in $19.5 \%$ (Figure 2). The discriminant analysis was able to identify a significant variation among the ornamental pepper progenies.

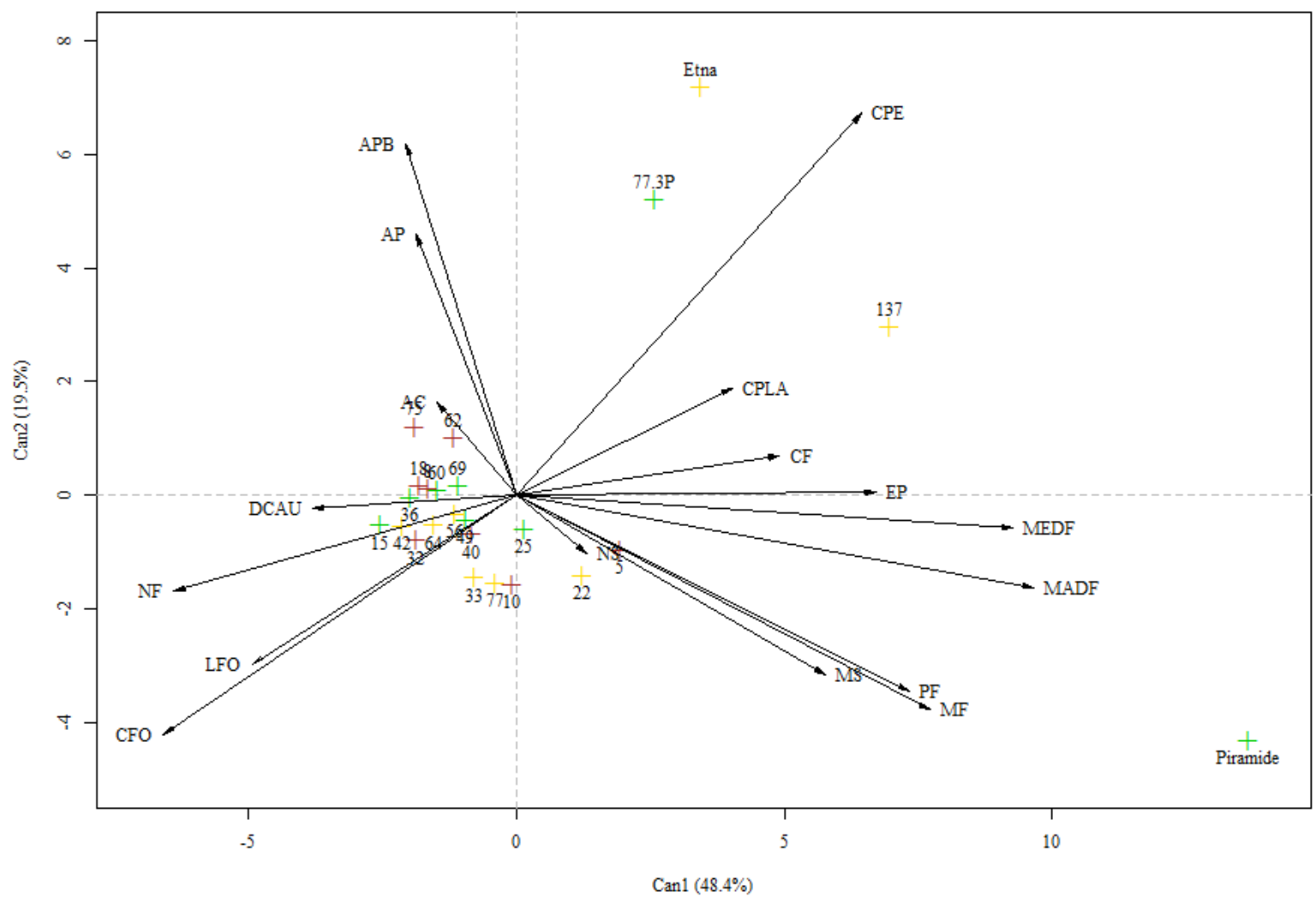

Figure 2. Dispersion of the scores of the first two canonical variables (CAN1 and CAN2) obtained based on the morphoagronomic traits of 24 ornamental pepper populations (C. annuum L.). Plant height (AP), crown diameter (AC), first bifurcation height (APB), stem diameter (DCAU), leaf length (CFO), and leaf width (LFO). The fruit traits evaluated were: pedicel length (CPE), fruit weight (PF), fruit length $(\mathrm{CF})$, largest fruit diameter (MADF), smallest fruit diameter (MEDF), pericarp thickness (EP), placenta length (CPLA), fresh matter (MF), number of seeds (NS), dry natter (MS), and number of fruits (NF).

This variation verified among the progenies is the raw material for genetic improvement, so it is necessary to perform selection in the advancement of segregating generations (PESSOA et al., 2019).

According to the graphic dispersion of the progenies in the two-dimensional space using the first canonical variables, it was evidenced that the traits of plant height, crown diameter, first bifurcation height, leaf width, pedicel length, pericarp thickness, and placenta length contributed more to the distance between the populations of ornamental peppers (Figure 2). The plant traits contributed the most to the distance between progenies, being able to select populations with different use potentialities; for example, those with smaller sizes are recommended for in-pot cultivation (BARROSO et al., 2012; PESSOA et al., 2018).

Similar results were found by Silva et al. (2014) when working with $C$. annuum, reporting that the traits that contributed the most to diversity were also the traits related to the plant. These results coincide with those obtained by Mesquita et al. (2016), who reported that the traits of crown diameter, leaf width, and first bifurcation height contributed the most to the distance between the $F_{3}$ populations of ornamental peppers. Using the plant traits, it is possible to select genotypes with desirable ideotypes for in-pot ornamental cultivation, with small size and low bifurcations, providing a harmonious relationship when associated with crown and pot height and diameter and providing the plants with greater aesthetical quality (SEGATTO; MATTIUZ; MOZAMBANI, 2006). Although they are segregating populations, it is already possible to select families with superior traits compared to the cultivars already available in the market.

According to the Scott-Knott test at 5\% probability, a large number of groups was originated (Figure 3), in addition to the formation of groups with only one progeny; these progenies showed greater dissimilarity (VASCONCELOS et al., 2007). The number of groups established is an indication of 
the wide variability that exists within progenies. This variability is important for selecting genotypes with ornamental potential (SILVA NETO et al., 2014; PESSOA et al., 2015).

It was possible to observe that the additional controls formed different groups (Figure 3), which was expected since more homogenous groups are formed in the Scott-Knott test. This justifies that the additional controls exhibit different traits in relation to the segregating populations.

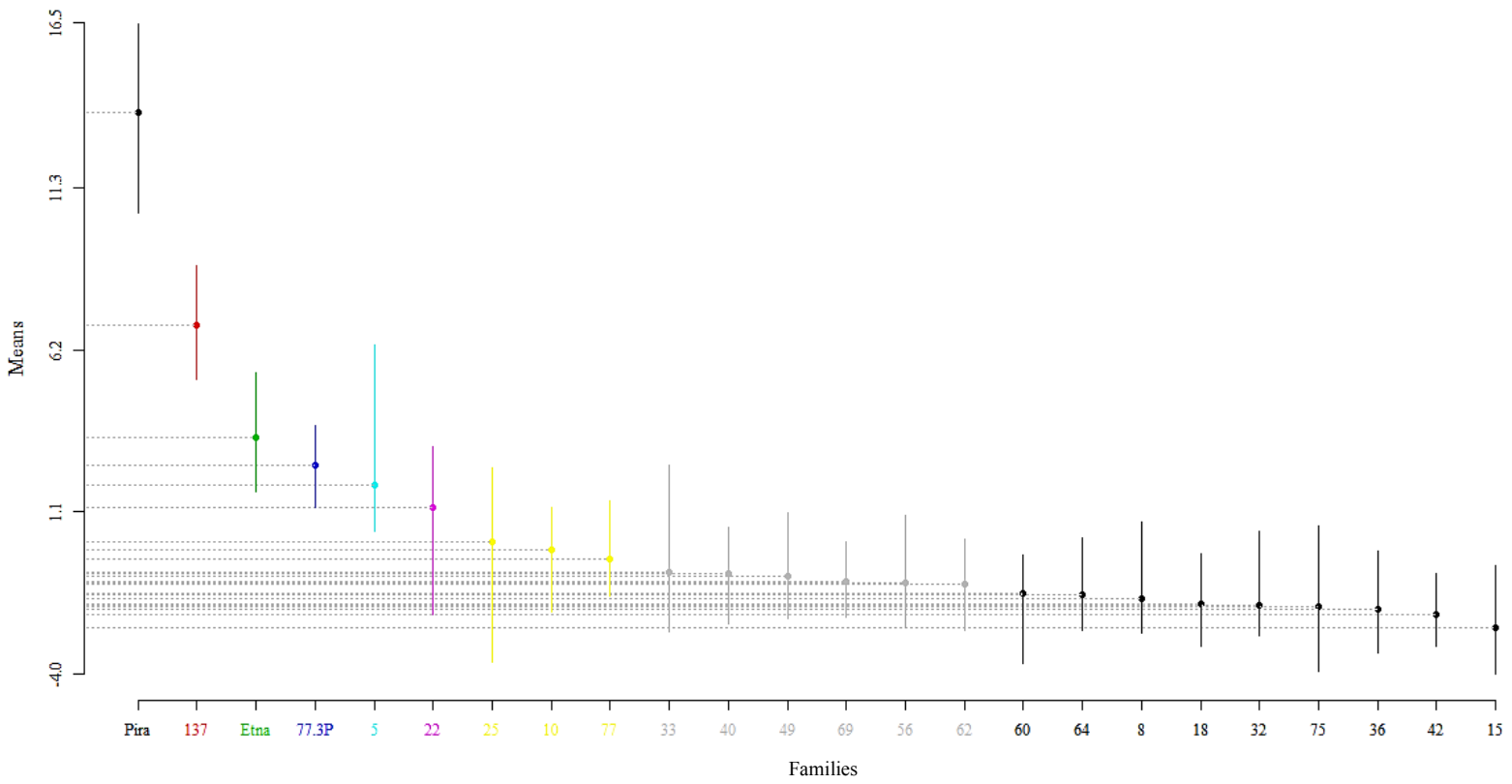

Figure 3. Grouping according to the Scott-Knott criterion for 20 Capsicum annuum populations and four additional controls performed based on the canonical analysis and the generalized distance of Mahalanobis. Group 1- Pirâmide; Group 2- 137; Group 3- Etna; Group 4- 77.3; Group 5- 5; Group 6- 22; Group 7- 25, 10, and 77; Group 8- 33, 40, 49, 69, 56, and 62; Group 9- 60, 64, 8, 18, 32, 75, 36, 42, and 15 .

Group 1 was formed by the additional control Pirâmide (Figure 3), a commercial variety consisting of small plants with low bifurcations, fruits with a thicker pericarp, and larger pedicels (Table 5). The parent UFPB 137, used as a control, formed Group 2 (Figure 3), consisting of small plants with small leaves and light fruits (Table 5). On the other hand, the additional control Etna formed Group 3 (Figure 3), with tall plants, high bifurcations, and fewer fruits. In turn, the parent 77.3, used as a control, constituted Group 4 (Figure 3), with similar characteristics to Group 3, showing tall plants with high bifurcations, in addition to lower values for stem diameter (Table 5). The specific characteristics of the controls distanced them from the remaining progenies and allowed the formation of different groups.

Group 5 was formed by population 5, and Group 6 was formed by population 22 (Figure 3), constituting progenies that resulted in small plants with low bifurcations (Table 5). Progenies with low bifurcations are desirable for breeding programs of ornamental peppers for in-pot cultivation to reduce plant size (NASCIMENTO et al., 2019) and allow cultivation in relatively small containers without compromising plant growth and development.

Group 7 gathered progenies 25, 10, and 77, while Group 8 gathered progenies 33, 40, 49, 69, 56, and 62 (Figure 3). Some progenies stand out for being smaller compared to other progenies of the same group, such as progenies 10, 33, 49, and 69, besides showing plants with large leaves and fruits (Table 5). Smaller ornamental pepper plants with small leaves are better harmonized with smaller fruits, while plants with large leaves are better harmonized with larger fruits. This set of traits is what makes plants attractive to customers (PINTO et al., 2010). 
Table 5. Means of 17 plant and fruit quantitative traits evaluated in 20 populations of ornamental pepper (Capsicum annuиm L.) and four additional controls. CCA-UFPB, Areia, 2018.

\begin{tabular}{|c|c|c|c|c|c|c|c|c|c|}
\hline Family & AP & $\mathrm{AC}$ & $\mathrm{APB}$ & DCAU & $\mathrm{CFO}$ & LFO & CPE & $\mathrm{PF}$ & $\mathrm{CF}$ \\
\hline 5 & 25.10 & 28.83 & 10.15 & 0.66 & 3.74 & 1.68 & 1.37 & 1.16 & 1.56 \\
\hline 8 & 33.10 & 32.50 & 14.45 & 0.71 & 4.31 & 1.78 & 1.24 & 0.75 & 1.22 \\
\hline 10 & 21.10 & 26.35 & 8.46 & 0.80 & 3.59 & 1.51 & 0.99 & 0.77 & 1.27 \\
\hline 15 & 29.65 & 32.38 & 12.05 & 0.79 & 4.16 & 1.88 & 0.93 & 0.62 & 1.20 \\
\hline 18 & 34.55 & 30.23 & 14.00 & 0.81 & 4.11 & 1.84 & 1.01 & 0.54 & 1.03 \\
\hline 22 & 20.83 & 28.16 & 9.20 & 0.51 & 3.22 & 1.52 & 0.98 & 0.92 & 1.33 \\
\hline 25 & 27.80 & 28.60 & 14.25 & 0.73 & 4.05 & 1.75 & 1.20 & 0.66 & 1.03 \\
\hline 32 & 29.95 & 29.13 & 12.90 & 0.77 & 3.91 & 1.71 & 0.86 & 0.53 & 0.92 \\
\hline 33 & 21.75 & 24.03 & 10.55 & 0.76 & 3.60 & 1.63 & 0.90 & 0.65 & 1.02 \\
\hline 36 & 32.93 & 31.63 & 13.77 & 0.75 & 4.11 & 1.76 & 1.01 & 0.74 & 1.30 \\
\hline 40 & 27.08 & 27.68 & 11.83 & 0.80 & 4.17 & 1.68 & 1.19 & 0.73 & 1.14 \\
\hline 42 & 27.25 & 27.70 & 13.45 & 0.71 & 3.65 & 1.58 & 0.86 & 0.55 & 1.02 \\
\hline 49 & 23.40 & 24.80 & 10.68 & 0.67 & 3.09 & 1.35 & 1.12 & 0.74 & 1.28 \\
\hline 56 & 28.15 & 27.70 & 14.43 & 0.75 & 3.84 & 1.77 & 1.09 & 0.67 & 1.09 \\
\hline 60 & 29.28 & 27.13 & 15.30 & 0.78 & 3.63 & 1.64 & 0.98 & 0.51 & 1.06 \\
\hline 62 & 32.65 & 30.88 & 15.80 & 0.69 & 3.52 & 1.57 & 1.11 & 0.59 & 1.26 \\
\hline 64 & 29.60 & 28.63 & 14.13 & 0.76 & 3.48 & 1.50 & 0.85 & 0.36 & 0.71 \\
\hline 69 & 24.50 & 28.20 & 12.15 & 0.76 & 4.03 & 1.81 & 1.21 & 0.83 & 1.45 \\
\hline 75 & 36.30 & 30.38 & 17.58 & 0.85 & 4.50 & 2.04 & 1.24 & 0.54 & 1.18 \\
\hline 77 & 29.70 & 31.03 & 11.05 & 0.73 & 4.23 & 1.85 & 1.02 & 0.95 & 1.32 \\
\hline UFPB77.3 & 45.80 & 40.13 & 15.33 & 0.58 & 1.94 & 0.99 & 2.01 & 0.24 & 0.75 \\
\hline Etna & 28.13 & 23.73 & 20.23 & 0.74 & 2.05 & 1.03 & 2.63 & 1.10 & 2.03 \\
\hline Pirâmide & 23.47 & 26.67 & 8.97 & 0.60 & 2.21 & 1.10 & 1.83 & 2.32 & 1.92 \\
\hline UFPB137 & 25.73 & 25.40 & 11.83 & 0.60 & 1.10 & 1.38 & 1.96 & 0.80 & 1.42 \\
\hline Family & $\mathrm{MDF}$ & MEDF & EP & CPLA & $\mathrm{MF}$ & NS & MS & & $\mathrm{NF}$ \\
\hline 5 & 0.82 & 0.40 & 0.07 & 1.07 & 0.90 & 28.00 & 0.14 & & 63.90 \\
\hline 8 & 0.65 & 0.33 & 0.04 & 0.84 & 0.49 & 35.00 & 0.08 & & 124.60 \\
\hline 10 & 0.63 & 0.31 & 0.06 & 0.90 & 0.60 & 26.00 & 0.09 & & 98.05 \\
\hline 15 & 0.51 & 0.26 & 0.04 & 0.82 & 0.40 & 24.00 & 0.07 & & 164.05 \\
\hline 18 & 0.53 & 0.29 & 0.06 & 0.70 & 0.39 & 25.00 & 0.07 & & 118.15 \\
\hline 22 & 0.80 & 0.39 & 0.05 & 0.96 & 0.61 & 31.00 & 0.09 & & 93.00 \\
\hline 25 & 0.69 & 0.37 & 0.05 & 0.71 & 0.48 & 26.00 & 0.08 & & 108.90 \\
\hline 32 & 0.50 & 0.27 & 0.05 & 0.62 & 0.38 & 24.00 & 0.06 & & 129.05 \\
\hline 33 & 0.58 & 0.30 & 0.06 & 0.73 & 0.49 & 26.00 & 0.08 & & 109.55 \\
\hline 36 & 0.56 & 0.29 & 0.05 & 0.92 & 0.53 & 25.00 & 0.09 & & 144.10 \\
\hline 40 & 0.65 & 0.34 & 0.05 & 0.84 & 0.51 & 30.00 & 0.09 & & 98.90 \\
\hline 42 & 0.51 & 0.27 & 0.04 & 0.70 & 0.36 & 26.00 & 0.06 & & 154.05 \\
\hline 49 & 0.60 & 0.29 & 0.08 & 0.83 & 0.57 & 32.00 & 0.08 & & 155.15 \\
\hline 56 & 0.57 & 0.29 & 0.05 & 0.71 & 0.48 & 27.00 & 0.07 & & 128.85 \\
\hline 60 & 0.55 & 0.28 & 0.05 & 0.71 & 0.37 & 24.00 & 0.06 & & 149.25 \\
\hline 62 & 0.51 & 0.26 & 0.04 & 0.81 & 0.45 & 19.00 & 0.07 & & 115.10 \\
\hline 64 & 0.50 & 0.31 & 0.05 & 0.49 & 0.25 & 21.00 & 0.05 & & 169.20 \\
\hline 69 & 0.56 & 0.26 & 0.07 & 1.08 & 0.63 & 23.00 & 0.10 & & 109.25 \\
\hline 75 & 0.55 & 0.29 & 0.04 & 0.79 & 0.36 & 25.00 & 0.07 & & 103.25 \\
\hline 77 & 0.63 & 0.29 & 0.04 & 0.90 & 0.73 & 23.00 & 0.11 & & 93.30 \\
\hline UFPB77.3 & 0.66 & 0.41 & 0.07 & 0.52 & 0.16 & 17.00 & 0.04 & & 116.40 \\
\hline Etna & 0.81 & 0.40 & 0.08 & 1.60 & 0.73 & 29.00 & 0.12 & & 18.00 \\
\hline Pirâmide & 1.65 & 0.73 & 0.14 & 1.16 & 0.87 & 29.00 & 0.20 & & 25.13 \\
\hline UFPB137 & 1.06 & 0.50 & 0.11 & 0.93 & 0.67 & 30.00 & 0.07 & & 48.93 \\
\hline
\end{tabular}

$\mathrm{AP}=$ plant height; $\mathrm{AC}=$ crown diameter; $\mathrm{APB}=$ first bifurcation height; $\mathrm{DCAU}=$ stem diameter; $\mathrm{CFO}=$ leaf length; $\mathrm{LFO}=$ leaf width; $\mathrm{CPE}=$ pedicel length; $\mathrm{PF}=$ fruit weight; $\mathrm{CF}=$ fruit length; $\mathrm{MDF}=$ largest fruit diameter; $\mathrm{MEDF}=$ lowest fruit diameter; $\mathrm{EP}=$ pericarp thickness; $\mathrm{CPLA}=$ placenta length; $\mathrm{MF}=$ fresh matter; $\mathrm{NS}=$ number of seeds; $\mathrm{MS}=$ dry matter; $\mathrm{NF}=$ number of fruits. 
However, Group 9 was formed by progenies $60,64,8,18,32,75,36,42$, and 15 (Figure 3), with plants showing high means for crown diameter, size, and bifurcations (Table 5). Barroso et al. (2012) report that, for in-pot ornamental peppers, crown diameter and plant height should correspond to 1.5 to 2 times the pot size. In this study, the ideal size would be from 21.10 to 25.73 for plant height and from 24.03 to 28.83 for the diameter since the pots used in this study had $16 \mathrm{~cm}$ and $13 \mathrm{~cm}$ of diameter and height, respectively. Progenies with taller plants are not interesting for in-pot ornamental cultivation, being recommended for open environments.

Based on these analyses, it was possible to verify the existence of genetic divergence among the progenies as well as the possibility of genetic gains in later selections (PESSOA et al., 2019). These results allow selecting contrasting families to advance generations and continue the breeding program of ornamental peppers.

\section{CONCLUSION}

There is genetic diversity among the evaluated $\mathrm{F}_{3}$ progenies of Capsicum annuum.

The methods used in this study were efficient to represent the genetic divergence among ornamental pepper progenies.

The Scott-Knott grouping method is recommended to assess the diversity in $F_{3}$ progenies of ornamental peppers for showing greater data variability for the different traits evaluated.

Progenies 5, 10, 22, 33, 49, and 69 are recommended for selection due to their superior ornamental traits for in-pot cultivation compared to the remaining progenies analyzed. Selection within these progenies is recommended to continue the breeding program of ornamental peppers for in-pot cultivation.

\section{REFERENCES}

BARCHENGER, D. W.; LAMOUR, K. H.; BOSLAND, P. W. Challenges and strategies for breeding resistance in Capsicum annuum to the multifarious pathogen, Phytophthora capsici. Frontiers in Plant Science, 9: 1-16, 2018.

BARROSO, P. A. et al. Analysis of segregating generation for components of seedling and plant height of pepper (Capsicum annuum L.) for medicinal and ornamental purposes. Acta Horticulturae, 953: 269-275, 2012.

BENTO, C. S. et al. Descritores qualitativos e multicategóricos na estimativa da variabilidade fenotípica entre acessos de pimenta. Scientia
Agraria, 8: 149-156, 2007.

COSTA, M. P. S. D. et al. Caracterização e diversidade genética de genitores de pimenta (Capsicum spp) e híbridos interespecíficos. Genetics and Molecular Research, 15: 1-12, 2016.

CRUZ, C. D.; CARNEIRO, P. C. S. Modelos biométricos aplicados ao melhoramento genético. Viçosa, MG: Universidade Federal de Viçosa, 2006. $585 \mathrm{p}$.

CRUZ, C. D.; REGAZZI, A. J.; CARNEIRO, P. C. $\mathrm{S}$. Modelos biométricos aplicados ao melhoramento genético. 4.ed. Viçosa, MG: Universidade Federal de Viçosa, 2012. 514 p.

CRUZ, C. D.; FERREIRA, F. M.; PESSONI, L. A. Biometria aplicada ao estudo da diversidade genética. 1. ed. Visconde do Rio Branco, MG, 2011. $620 \mathrm{p}$.

ELIAS, H. T. et al. Variabilidade genética em germoplasma tradicional em feijão preto em Santa Catarina. Pesquisa Agropecuária Brasileira, 42: 1443- 1449, 2007.

FERRÃO, L. F. V. et al. Divergência genética entre os genótipos de pimenta com base nos caracteres morfo agronômicos. Horticultura Brasileira, 29: 354-358, 2011

FORTUNATO, F. L. G. et al. Genetic diversity in ornamental pepper plants. Comunicata Scientiae, 10: 364-375, 2019.

IBRAFLOR - Instituto Brasileiro de Floricultura. O mercado de flores no Brasil. 2018. Disponível em: $<$ http://www.ibraflor.com/publicacoes/vw.php? $\operatorname{cod}=235 />$. Acesso em: 02 fev. 2018.

IPGRI - Instituto Internacional de Recursos Genéticos Vegetais. Descritores para Capsicum. IBPGR, Roma, 1995. 19 p.

LIMA, J. A. M. et al. Seleção na população base de pimentão ornamental (Capsicum annuum L.). Jornal de Agricultura Experimental Internacional, 31: 17, 2019

MELO, L. F. et al. Potencial ornamental de acessos de pimenta. Ciência Rural, 44 2010-2015, 2014.

MESQUITA, J. C. P. et al. Análise multivariada da divergência genética entre populações de pimenta ornamental (Capsicum annuum L.). African Journal of Agricultural Research, 11: 4289-4194, 2016.

NASCIMENTO, N. F. F. et al. Divergência genética e importância relativa para caracteres de porte, 
produção e qualidade de frutos em híbridos interespecíficos de pimenteiras ornamentais. In: CONGRESSO BRASILEIRO DE OLERICULTURA, 51., 2011, Viçosa. Anais... Viçosa: ABH, 2011. p. 2924-2931.

NASCIMENTO, N. F. F. et al. Evaluation of production and quality traits in interspecific hybrids of ornamental pepper. Horticultura Brasileira, 37: 315-323, 2019.

NEITZKE, R. S. et al. Pimentas ornamentais: aceitação e registro do público consumidor. Horticultura Brasileira, 34: 102-109, 2016.

OLIVEIRA, V. R.; SCAPIM, C. A.; CASALI, V. W. D. Diversidade genética e eficiência da predição do comportamento. Acta Scientiarum, 20: 263-267, 1998.

PESSOA, A. M. S. et al. Genetic diversity in F3 population of ornamental peppers (Capsicum annuиm L.). Revista Ceres, 66: 442-450, 2019.

PESSOA, A. M. S. et al. Genetic diversity among accessions of Capsicum annuum L. through morphoagronomic characters. Genetics and Molecular Research, 17: 1-15, 2018.

PESSOA, A. M. S. et al. Genetic diversity and importance of morpho-agronomic traits in a segregating $F_{2}$ population of ornamental pepper. Acta Horticulture, 1087: 195-200, 2015.

PICKERSGILL, B. Recursos genéticos e melhoramento de Capsicum spp. Euphytica, 96: 129 $-133,1997$.

PINTO, C. M. F. et al. Produção e qualidade de pimentas ornamentais comestíveis cultivadas em recipientes de diferentes volumes. Revista Brasileira de Horticultura Ornamental, 16: 113122. 2010.

R DEVELOPMENT CORE TEAM, R. A language and environment for statistical computing. $R$ foundation for Statistical Computing, Vienna, Austria, s/v: 2014.

RÊGO, E. R. et al. Produção de mudas e disponibilização de cultivares de pimenteiras: sustentabilidade, inclusão 10 social e geração de trabalho e renda nas comunidades de Macacos e Furnas no brejo paraibano. In: MIRANDA, M. V. C.; SOBRINHO, R. G. S.; RÊGO, E. R. (Eds.). Sustentabilidade, Inclusão Social e Geração de Trabalho e Renda - Perspectivas de Extensão Universitária. Areia, PB: Universidade Federal da Paraíba, 2012. v. 1, cap. 1, p. 11-30.
RÊGO, E. R.; RÊGO, M. M. Pimenta Ornamental. In: Van Huylenbroeck J, 1. ed. New York, Culturas Ornamentais. London, Springer International Publishing, 2018. 565 p.

RÊGO, E. R.; RÊGO, M. M. Genética e criação de pimenta. In: REGGO, E. R.; RÊGO, M. M.; FINGER, F. L. (Eds.). Produção e melhoramento de malagueta (Capsicum spp.). London: Springer, 2016. v. 1 , cap. 4 , p. 57-80.

SEGATO, S. V.; MATTIUZ, C. F. M.; MOZAMBANI, A. E. Aspectos fenológicos da canade-açúcar. In: SEGATO, S. V.; PINTO, A. S.; JENDIROBA, E. (Eds.). Atualização em produção de cana-de-açúcar. Piracicaba, SP: Livro Ceres, 2006. v. 1, cap. 2, p. 19-36.

SILVA NETO J. J. et al. Variabilidade em população base de pimenteiras ornamentais (Capsicum annuum L.). Revista Ceres, 61: 84-89, 2014.

SILVAR， C.; GARCÍA-GONZÁLEZ， C. A. Screening old peppers (Capsicum spp.) for disease resistance and pungency-related traits. Scientia Horticulturae, 218, p. 249-257, 2017.

SINGH, D. The relative importance of characters affecting genetic divergence. Indian Journal of Genetic and Plant Breeding, 41: 237-245, 1981.

STOMMEL, J. R.; BOSLAND, P. Ornamental pepper. Capsicum annuum. In: ANDERSON, N. O. (Ed.). Flower breeding and genetics: issues, challenges, and opportunities for the 21st Century: Dordrecht, Holanda: Springer, 2006. v. 1, cap. 21, p. $561-599$.

VASCONCELOS, E. S et al. Método alternativo para análise de agrupamento. Pesquisa Agropecuária Brasileira, 42: 1421-1428. 2007.

VIANA, A. P.; RESENDE, M. D. V. Genética quantitativa no melhoramento de fruteiras. Rio de Janeiro, RJ: Editora Intercedência, 1 ed. 2014.

YOKOMIZO, G. K.; NETO, J. T. F.; OLIVEIRA, M. S. P. Dissimilaridade morfológica entre progênies de açaizeiro provenientes de Anajás - PA. Revista de Ciências Agrarias, 60: 343-349, 2017. 